\title{
Re-Interpretation of Mañjuśrī in Central and East Java
}

\author{
Lesley S Pullen \\ Post-Doc Research Associate, SOAS, University of London, United Kingdom \\ Email: pullen.london@btinternet.com
}

\begin{abstract}
This article will begin with a brief look at the origins of Mañjuśrī from south Nepal, his popularity in China and the many depictions of him in eastern India and Java. More importantly, it will re-interpret a selected group of the Boddhisattva Mañjuśri in the human form with one head and two arms. The statues produced in both bronze, silver and stone, all with similar attributes identifying him as Mañjuśrī. The theoretical framework follows the various representation of Mañjuśrī statues from eastern India to a Kumārabhūta form only in Central Java and a single form of Arapacana in East Java. Within this framework, it will evaluate the stylistic features, attributes and the sartorial style of statues from both regions of Java, with details not previously discussed by past scholars, particularly looking at the textile patterns found on several of the statues.

When the Mañjuśrī statues appeared in Central Java, various forms of the youthful Kumārabhūta or royal prince emerged, where he appeared to be particularly popular. Despite past knowledge of these statues, this paper allows for a new research direction and highlights the change in Mañjuśrī styles from Central to East Java. Similarly, various forms of Mañjuśrī Arapacana from eastern India transpire in East Java with this one unique statue of Arapacana from Caṇ̣̣i Jago.
\end{abstract}

Keywords: art history; dress; iconography; Java; Mañjuśrī; sculpture; textile patterns

\section{INTRODUCTION}

Mañjuśrī is a bodhisattva associated with prajñ $\bar{a}$ (insight) in Mahāyāna Buddhism. He appears in several different forms in today's Bihar, Bengal and Bangladesh, and in Central and East Java. His name means "Gentle Glory" in Sanskrit, and the fuller name also knows him as Mañjuśrī Kumārabhūta, literally "Mañjuśrī as a youth/ prince". Mañjuśrī is one of the oldest and most significant Bodhisattva in Mahāyāna literature. In early Sutras, such as the Prajñāpāramitā sutra, he was known from the 4th century on both sides of the Himalayas, with images found in Sarnath, Magadha, Bengal, and Nepal. He wielded significant influence on the Buddhists, and the Mahāyānists worshipped him in various forms.

As a spiritual leader who originated from south Nepal, Mañjuśrī rose to popularity in China rather than India (Bhattacharyya, 1958:101; Gail, 1995:13; Maxwell, 1997:170; Miksic, 2006:208). ${ }^{1}$ In his study on Indian Buddhist Iconography, Bhattacharyya reports that no figural representation of Mañjuśrī was found in the Sarnath or Gupta School up to the 6th century. Snellgrove suggests that the Chinese monk Xuanzang mentions only one image of Mañjuśrī in the record of his pilgrimage to the Indian Subcontinent (Snellgrove, 1987:314). Moreover, according to Bhattacharyya, Mañjuśrī is one of the sixteen male bodhisattvas of the Buddhist pantheon and is second in the group headed by Maitreya. He and Avalokitésvara are the two most important gods of learning and two of the most widely venerated bodhisattvas (Bhattacharyya, 1958:94 \& 102; Maxwell, 1997:170).

From the 4th century, Mount Wutai became regarded as the home of Mañjuśrin, with which he is associated. It became one of China's premier Buddhist pilgrimage sites from the end of the 5th century, attracting 
travellers from all over Asia, including Amoghavajra, known as a devotee of Mañjuśrī. In addition, this formerly distant pilgrimage site at Wutai played an essential role in transmitting Buddhist doctrines outside of China to Japan, Korea and Southeast Asia. (Kieschnick, 2015:199; Miksic, 2006:186). Subsequently, many societies across Asia became integrated through these Buddhist networks, promoting cross-cultural exchanges (Sen, 2009:36-7). As a result, we have specific knowledge about Mañjuśrī in almost all the countries in Asia where Buddhism held sway. However, the examples of Mañjuśrī, which made it to Java, were limited compared to those present in India. As Bhattacharyya has noted (1958:94-5), the several countries in Asia that adopted Mañjuśrī appear to have conceived their forms. These forms are apparent in the examples presented in this paper; however, it is difficult to trace the prototypes behind locally inspired interpretations without further textual references. In Java, Mañjuśrī appears in human form (with two arms and one head) as a youth with braided hair and vyāghranakha, a medallion set between two tiger claws to form a necklace as seen in figure $7 \& 8$ (Bautze-Picron, 1989:75, Gail, 1995:135). Depictions of him holding a sword and a book is the subject of eight Sädhanas, in which he has fourteen names. Arapacana being the most common and widely used of this form of Mañjuśrī often accompanied by his four attendants, as required by the Sädhana (Bhattacharyya, 1958:120-21), as the East Java example shows in figure 10.

A small number of scholars have written about Mañjuśrí in India and Java, but there has not been an extensive study of the various styles of this bodhisattva. The theoretical framework of this paper brings together previously unpublished Mañjuśrī statues as a group. It re-interprets the statues reflecting on the work of past scholars in the brief literature review and expanded on in this article. This paper brings together eleven Central Java statues and the only statue from East Java as a cohesive group.

As suggested by Long (2015:19), the Old Malay Mañjuśrīgrha inscription (792 CE), found in the southwest corner of the Candi Sewu yard, announced the construction and the enlargement of a grand prāsā $d a$ or monument. A mañjuśrigrnha that is likely to refer to Candi Sewu; according to Long, a statue of Mañjuśrī found on a corner pedestal of the East Shrine at Candi Sewu (2015 Nov:14). Mañjuśrīgrha was a Buddhist building designed to contain the wisdom of the Buddha, Dharma and Sañgha as a Mañjuśrī statue (Soekmono, 1995:54). The building might have housed an image of Mañjughosa (Degroot, 2013:117; Miksic, 2006:189).
Long (2015 Nov:19), discusses the issues of the $S r \bar{l}$ Sañgrämadhanañjaya inscription of $782 \mathrm{CE}$ and whether it was associated initially with Caṇḍi Sewu or Caṇḍi Lumbung, notes that Mañjuśri is not only the central focus of these inscriptions, but the primary Buddhist divinity mentioned there. Dumarçay advocates that the Old Malay Kelurak inscription (782 CE) is related to Candi Lumbung and that the statue of Mañjuśrī was inside Caṇdi Sewu up until the year $790 \mathrm{CE}$. The $792 \mathrm{CE}$ inscription mentions the second stage of construction, during which the temple was adapted as a mandala. The mandala is similar but not identical to a Vajradhātumandala; however, Sewu primarily dedicated to Mañjuśrī (Dumarçay, 1981:207). Soekmono refers to Bosch who "concluded that the manifestation of the Buddhist Triratna and the Hindu Trimūrti in Mañjuśrī proved that the Kelurak inscription described the creation of a Tantric mandala" (Soekmono, 1995:55). Long also quoted Bosch as stating that the $\dot{S} r \bar{r}$ Sañgrāmadhanañjaya inscription appears to identify Mañjuśrī equally with the Triratna and the Trimūrti. This fact led Long to conclude that the inscription refers to Caṇdi Lumbung with Mañjuśrī manifested in union with this Buddhist temple and at the Hindu temple at Prambanan (Bosch, 1961:125; Long, 2015 Nov:20).

Jordaan discusses the Kelurak inscription mentioning the Indian guru Kumāraghoșa who came from Gaudīidvīpa to Java and officiated at the consecration of the Mañjuśrī shrine. Gauḍivișaya is a district in Eastern Bengal where the Buddhist cruciform temple located at Paharapur. This idea perhaps suggests that the ground plan of Sewu is derived from the Paharpur shrine and possibly transmitted by Kumāraghoșa to Java. Jordaan also proposes the ground plans for Caṇịi Sewu might have arrived with a Javanese pilgrim returning from Nālandā in eastern India (1993:28-9).

The popularity of Mañjuśrī within the Buddhist pantheon is in evidence by as many as forty-one sädhanas dedicated to him, where the iconography of Mañjuśrī is well-attested in the Sädhanamāla (SM). Therefore, it is only natural that the possible cult of this bodhisattva travelled to Java, resulting in the construction of one or more temples dedicated to him. Perhaps the Śailendra rulers saw in him a powerful deity to protect their royal status and their people. From the extant statuary vestiges, it is perhaps significant to note the importance the Central Javanese rulers gave to Mañjuśrī, as there appear to be many substantial stone statues and many small metal icons. Furthermore, Miksic, who has published extensively on Mañjuśrī, has interpreted several lines of the Kelurak inscription, particularly lines 1417, showing that the role Mañjuśrí plays emphasised 
protection and victory and exerted a benign influence on all beings (2006:189). He also shows that in the 8th century, epigraphic and architectural remains suggest that Mañjuśrī was a prominent bodhisattva revered by the Śailendra rulers, highlighting the possible existence of a Mañjuśrī cult in this context.

During the Pāla period, Arapacana appears to be one of the most popular forms of Mañjuśrī in both stone and bronze. ${ }^{2} \mathrm{He}$ is defined with a sword raised in the right hand, the left hand clasping the Book of Perfect Wisdom, with eight sādhanas dedicated to him (Bhattacharyya, 1958:28; Mallmann, 1964:26-7). Maxwell suggests the Mañjuśrī as the centre of his Pentad complete with his $b \bar{i} j a$-mantra was used for meditational purposes. All the accompanying deities sit in the same posture and hold similar attributes. Maxwell (1997:172-3) states that the accompanying deities are usually not distinguishable from each other and points to the vital role of the sädhana in Vajrayāna in the 11th and 13th centuries. All these aspects of iconography are evident in the 13th century East Java Arapacana example.

A re-interpretation of the icons of Mañjuśrī found in Java follows with both bronze and stone statues only, in the seated position. Some remain in situ in Central Java; however, most remain in museums worldwide. There is only one extant statue of Mañjuśrī originating from East Java which will be discussed in further detail regarding how it came to be in the State Hermitage Museum. The theoretical framework includes ideas already published; how do Javanese and Pāla styles of Mañjuśrí icons differ? To answer, we can look at the two regions through a different lens by re-interpreting these ideas in the broader sense.

\section{DISCUSSION}

\section{Stylistic features and attributes}

The theoretical framework includes ideas already published; how do Javanese and Pāla styles of Mañjuśri icons differ? To answer, we can look at the two regions through a different lens by re-interpreting these ideas in the broader sense.

The Pāla style was defined in the image of the bronze casting and the typical form of dress and other elements, especially relating to facial features, $m u d r \bar{a}$, posture, the material and size, and a greater variety of forms with more elaborate ornaments. From extensive research into sculptures in both bronze and stone, it is clear that gender and religious affiliation, i.e. whether a statue was of Śaivite or Esoteric origin, did not affect the sartorial style on any given figure. If no texts remain, that indicate a statue's source, an iconographic and stylistic comparative appraisal are the only means of identifying and dating Pāla and Javanese bronzes (Bautze-Picron, 2007:2). Some of the earliest Javanese bronzes could indeed have originated in Southeast Bangladesh in the Maināmatī region, as is evident from a Mañjuśrī Kumārabhūta in a private London collection, in figure 8. ${ }^{3}$ These early Javanese statues were produced before the (SM) collection of Sādhanas. ${ }^{4}$ This text probably dates from the 11th century and describes various incarnations of Mañjuśrī, but, as Bhattacharya has indicated, the artists had considerable freedom to create their innovations and traditions. Moreover, the votaries wanted their deities in the most potent form, so the artists would add extra heads or arms to suit their taste (1958:34); however, this aspect is not apparent in Java.

Javanese statues of Mañjuśrī sit or stand on a pedestal or pit tha cast in many varieties of shapes and sizes. Animals seated beneath Javanese figures of Mañjuśrī are rare. Generally, the base of these icons depicted as an inverted lotus cushion and often placed on a square platform or a mostly rounded cushion representing the lotus petals.

The representation of the water lily held by Mañjuśri differs from the lotus in that the petals are closed, elongated in form, and presented in profile. Sometimes the first row of outside petals is turned back, but the petals permanently hide the centre of the utpala. Examples of Mañjuśrī Arapacana occasionally appearing in contemporary Thangka painting in China ${ }^{5}$ and on 20th-21st-century bronzes in Nepal and Tibet are depicted with a vajra or dorje pommel or handle, a feature unknown under the Pāla. However, the East Java Mañjuśrī is depicted with a vajra pommel and the Prajñāpāramitā sütralpustaka as a manuscript shown on top of the utpala to the left of the body. Sometimes we see a sword placed upright on top of the book or flower, as we see in the Khorat image and the Central Java statue of Sthiracakra in figure 9. The Asia Society Khorat bronze of similar iconography is called Sita Mañjughoșa by Mallmann (1964:43), Sthiracakra by Bhattacharya (1958:122) or Sthiracakra-Mañjughoșa by Mitra (1978). Both icons are highly unusual, and neither statue could be of Pāla origin, given the facial features and the relatively simple ornaments and textile pattern. In the Java example, it is called Sthiracakra.

Certain aspects of iconography, such as the channavira, the crossed chains, is substituted by the yogapatta, a crescent moon or wings that often appear behind his head, can all identify the statues originating from Java (Miksic, 2006:201). The hairstyles generally 
vary from a tall conical crown enmeshing jewels, tiaras and diadems to a kirittamukuța and free-falling ringlets over each shoulder. The curls formed by pulling the hair to the top of the head and three high-piled loops created, as suggested earlier, a style that may have derived from Mañjuśrī at Wutai Shan. This hairstyle is prevalent in Pāla and Javanese sculptures and appears on most of the statues portrayed in this chapter but various forms. La Plante thinks that this hairstyle restricted to a short period, especially in north India (1963:269-70).

In the Mogao Cave 98 in China (AD 925), Mañjuśrī, who flanks the entrance, displays the crescents behind his head and three hair curls. Miksic believes this to be a Javanese innovation (2006:209); Miksic also suggests that even if this were the case, some examples in-between Java and China must exist. At the Yulin Gang in the passageway to Cave 28 stands a young man, a bodhisattva with a crescent behind his head, which Miksic suggests could be Mañjuśrī. However, I am not able to verify this claim. As there are no other attributes in this early Tang image, Miksic also proposes the crescent moon was likely of Chinese origin (2006:209) and suggested some intermediary examples must exist. However, as there is very little evidence in China of other images of Mañjuśrī, this specific attribute of the crescent shape, I would argue, is probably of Javanese innovation. However, the examples might also be a coincidence. This research has shown there is no such intermediary example.

Huntington describes the style of the Javanese bronzes as "displaying extraordinary richness, stylistic sophistication and technical virtuosity" (1990); perhaps another description would be that the statues, especially their faces, reflect precision and sweetness of expression which lies in the refinement and beauty of their appearance. The muscular structure of the body beneath the robe is apparent in both Pāla and Central Javanese statues. The kain reaching the ankles, the hair falling on the shoulders in three ringlets, and the style of the crown all evolve from a Pāla aesthetic.

\section{Javanese Sartorial Styles}

The theoretical framework in this section uses Javanese sartorial style as a valuable indicator of the origin of a statue which can be the detail of the dress. Dress includes four essential parts of apparel-first, the filet or crown and its ties. Second, the upavitta or yajnopavita (sacred thread). Third, the uttariya or seléndang, the broadband or sash draped across the upper body and folded over the left shoulder, or worn as a long narrow scarf across the shoulders with the ends flowing freely. Lastly, the dhotī or antariya is both a short and long hip wrapper in Central Java. This latter garment was later supplanted in East Java by the kain or sinjang or long cloth. This cloth is held in place by a metal girdle or belt, which often appears on the statues with the ends laying on the lotus cushion.

Similarly, a particular feature of late East Java is a broad sash laid across the hips and tied at the sides in a bow of varying sizes, as seen behind the hips of the Hermitage Mañjuśrī in figure 10. Finally, the upavīta, not always apparent, is characteristically represented on the Pāla sculptures as a long metal chain held with an ornate clasp at the left breast and adopted in East Java as a four-strand pearl chain. In some cases, like the Rijksmuseum Kumārabhūta from Central Java in figure 1, we see a channavira worn by young boys, an Indian form of ornament rarely shown on Pāla Kumārabhūta statues.

The re-interpretation of this period looks at textiles that have disintegrated with climate and time; therefore, statuary is their sole repository. The best example is the one incised into the smooth pale andesite stone of the Hermitage Arapacana from East Java, which shows a repeated pattern of roundels inset with foliate leaves and mythical creatures emerging from the foliage on contiguous roundels as seen in figure 10a. Textiles had a significant function in Java and India as status, prestige, and in some instances, as protection. For example, Indian cotton imports bore generic patterns as seen on Indian statues. However, the Javanese bronzes, including the Hermitage Arapacana, show various Indian, Sasanian, and indigenous origins, ${ }^{6}$ many of which highlight the perhaps royal status of the statue.

\section{Central Javanese Icons of Mañjuśrī}

This section re-interprets eleven statues in bronze and stone as a group of Mañjuśrī Kumāra statues originating from Central Java, one of which remains in situ at Sewu. The remainder is in various museums worldwide. In 9thcentury Central Java, Mañjuśrī mostly appears as Mañjuśrī Kumārabhūta or 'youthful Mañjuśrī', to be known here as Kumāra. The first statue is one of the two seated examples of stone Mañjuśrī found at Caṇ̣i Plaosan, according to Southworth (2017:264). The statue now remains on view in the Rijksmuseum in Amsterdam (Fig. 1). Mañjuśrī is seated against a decorated backplate, his eyes downcast in deep meditation; behind his head are the projection as two wings or crescent moons; his features are classic Central Javanese, with a fleshy nose and full lips. Decorated with a bejewelled channavira, elaborate necklet, and upper armbands, his missing hands presumed to have been in dharmachakra mudrā. The jewelled girdle ends fall over the lotus cushion along with the pleated ends to the waist 


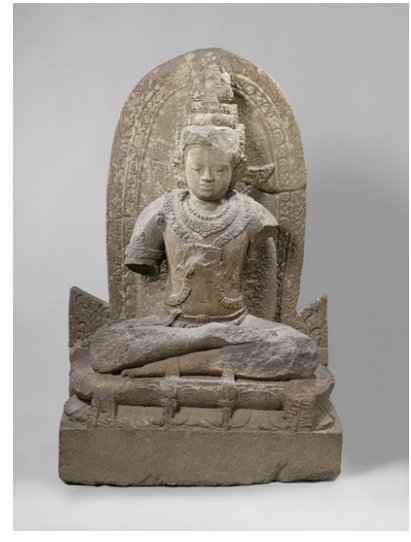

Figure 1. Mañjuśrī Kumārabhūta, Central Java, Caṇdi Plaosan, Stone, early 9 th century, $1.38 \mathrm{~cm}$, Rijksmuseum, Amsterdam, Inv. No. AK-MAK-240

sash. His hair formed in either three or five curls known as tricīra or śikhandak (Gail, 1995:135-6; P Lunsingh Scheurleer, 1988:82; Southworth, 2017:262), which de Mallmann calls the coiffure of a young man (1964:28). ${ }^{7}$ I would argue that this Mañjuśrī wears a crown of a prince and does not have the sikhandaka hairstyle.

The other seated Mañjuśrī was in situ (Southworth, 2017:262) but no longer found as of 2019. ${ }^{8}$ The Plaosan complex consists of two Buddhist temples, Plaosan Lor (or north) and Plaosan Kidul (or south). ${ }^{9}$ Highlighting that there were many statues of Mañjuśrī created for the Sewu/ Plaoson complex in the ninth century. In 2006 Miksic describes a statue of Mañjuśrī amongst other mutilated statues at Plaosan Lor; in fact, he described many possible statues of Mañjuśrī amongst other bodhisattvas placed on a stone bench on the north side of the complex (2006:206). However, at the time of field research in 2019, these statues are no longer found here. Perhaps it is essential to note the new data added to this field of research - for example, this next unpublished statue at Plaosan Lor.

What does remain within Plaosan Lor are three cells: in the southern cell is a statue of Avalokitésvara on the left, the central figure is missing, and the second statue in stone is of Kumāra who appears on the right (Fig. 2), the only statue of Mañjuśrī still in situ. This large stone Kumāra is seated in lalitāsana on a lotus cushion set upon a high platform. Placed against a backslab with an ogival shape around which the border decoration is similar in style to figure 1. His hair appears more closely to that of figure 1 than the typical three hair curls of Kumāra. The Mañjuśrī appears adorned with a large chain channavīra

held with a jewelled clasp along with a sizeable necklet and elaborate upper armbands. The armbands reflect the types of gold ornaments as seen in collections from the National Museum, Jakarta (Wahyono, 1999:32); this attire echoes the ornaments of a princely figure. The blue lotus or utpala is held in the damaged left hand and supported by his forearm, with the flower appearing on the backplate supports the book (Mallmann, 1964:24). Two aspects of his attire similar to figure 1 are the jewelled girdle tassels and pleated ends of the sash appearing on the front of the lotus cushion. The two definite iconographical features of Mañjuśrī Kumāra are the crescent moons behind his head and the book held on the blue lotus.

The following two bronze Kumāra from the British Museum (Fig. 3 and 4) are seated in lalitāsana on a sizeable ball-shaped lotus cushion raised on two platforms. Both bronzes are part of the Raffles Collection. ${ }^{10}$ Figure 3 is leaning on his left arm, whereas figure 4 holds a lotus bud in the left hand; both adorned with a long chain upavita falling over the left ankle, across the body of figure 4 is also a broadband sash or seléndang. They both appear to exhibit the five hair curls, but behind the head of figure 3 is the triangular projections, as seen earlier-the kain or hip cloth appears at the knee on figure 3 and the ankles in figure 4. Finally, Figure 4 is the only statue in this group from Central Java with an open work halo surrounded by curling flames. The facial features and body proportions are both Central Javanese.

The following four statues, three in bronze and one in silver, have not been published before as a group.

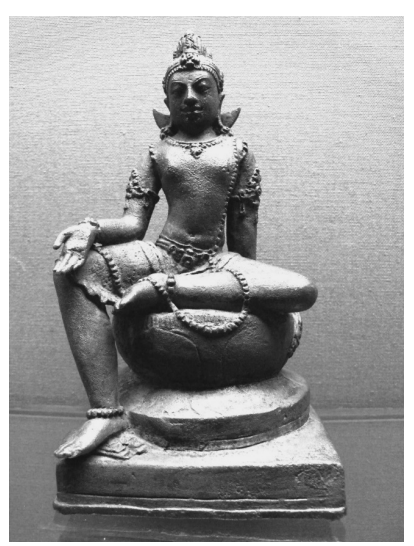

Figure 3. Mañjuśrī Kumārabhūta, Central Java, Bronze, early 9th century, British Museum, Inv. no. $1859,1228.25$, Donated by Rev. William Charles Raffles

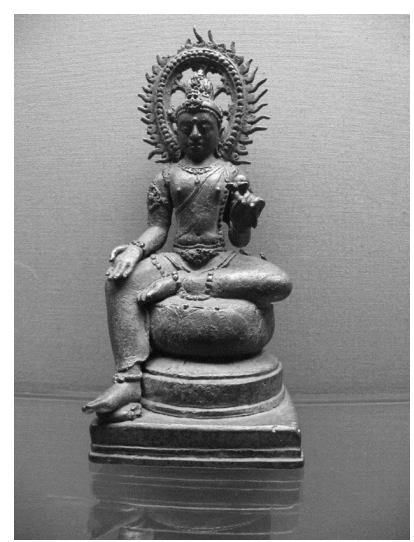

Figure 4. Mañjuśrī Kumārabhūta, Central Java, Bronze, 9th to 10th century, British Museum, Inv. no. 1939.0312.1, Donated by Mrs J H Drake, Collection of Raffles 

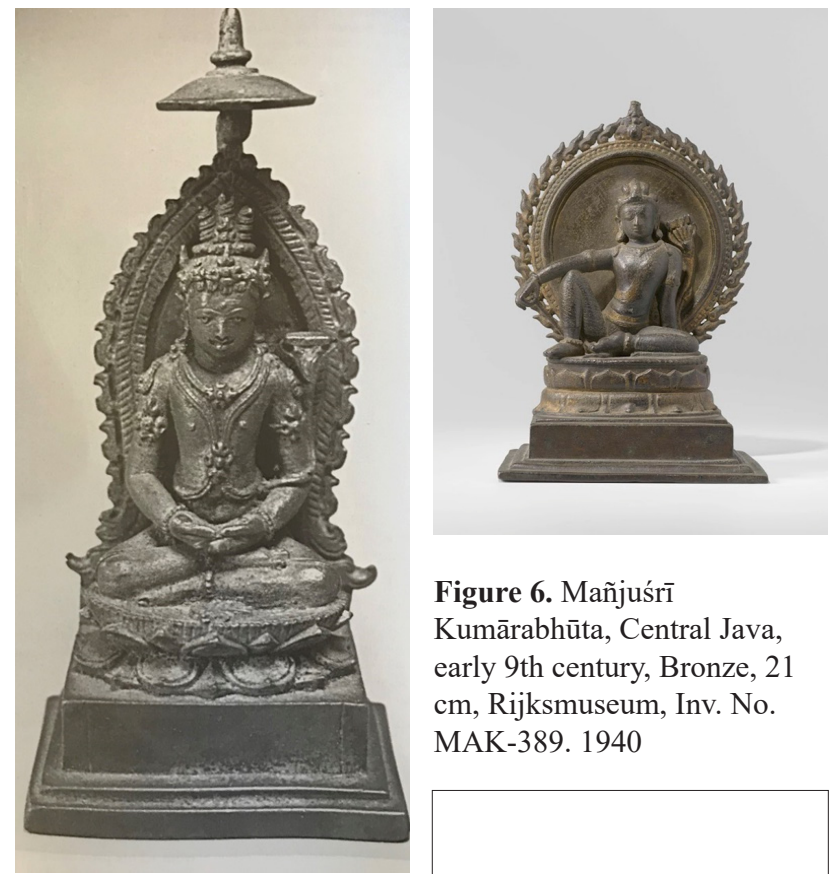

Figure 6. Mañjuśrī

Kumārabhūta, Central Java, early 9 th century, Bronze, 21 $\mathrm{cm}$, Rijksmuseum, Inv. No. MAK-389. 1940

Figure 5. Mañjuśrī

Kumārabhūta, Central Java, late 9 th to early 10 th century, Bronze, $10.7 \mathrm{~cm}$. After "Divine Bronze: 82)

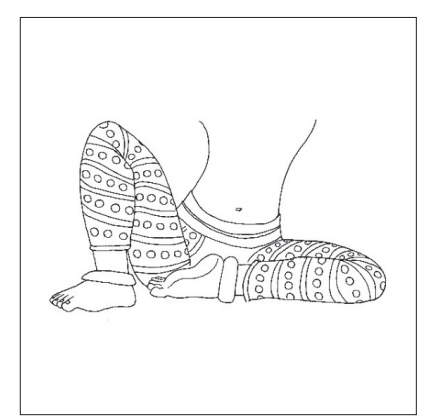

Figure 6a. Drawing of the textile pattern by Yiran Huang

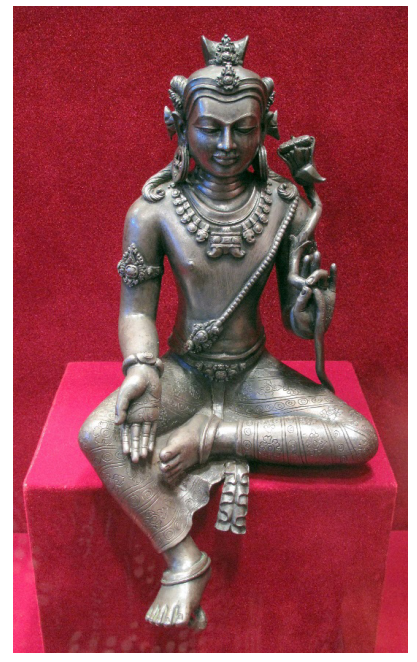

Figure 7. Mañjuśrī Kumārabhūta, early 10 th century, Ngemplak Semangan, Semarang, found in 1927. Museum Nasional Indonesia. $28 \mathrm{~cm}, 92 \%$ silver, $8.25 \mathrm{~g}$. Inv. no. 5899/A.1105.

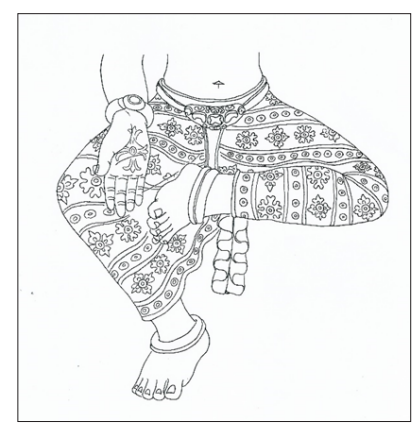

Figure 7a. Drawing of the textile pattern by Yiran Huang

features and dress (1988:73). An exciting feature is the carved textile pattern of circles set between horizontal bands, perhaps suggestive of an Indian block printed and mordant dyed cotton in Fig. 6a; this feature is not visible on Orissa bronzes of the same period, suggesting this is more likely of Javanese origin (Pullen, 2021:81-2).

The renowned silver Kumāra at the Museum Nasional Indonesia (Fig. 7), published many times, is seated in lalitāsana with the right palm open in varada $m u d r \bar{a}$, the palm tattooed with the image of a viśvajra a symbol of two crossed vajra, this fact is not recognised in past literature. His iconography bears all the features of Kumāra, the three hair curls, the book on the lotus, the necklace mounted with an amulet of tiger claws held together at the base and inserted into a metal holder. According to Untracht (1997:91), the amulet on this Javanese Mañjuśrī is mainly Indian in origin. The overall iconography also seems to be principally Indian and appears to follow the strict rules of Pāla style; this statue has been described in great detail by Fontein, where he 


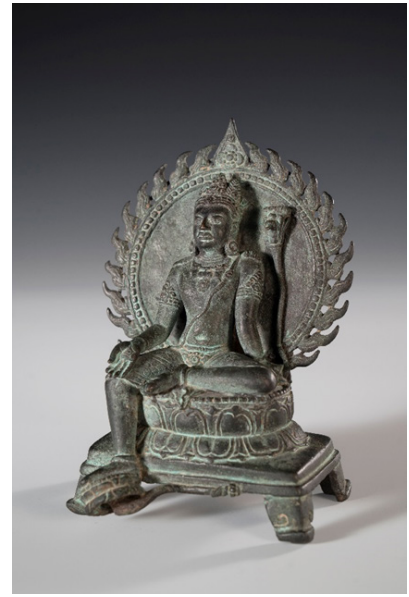

Figure 8. Mañjuśrī

Kumārabhūta, Central Java, 9th century, origin unknown, bronze. $13.6 \mathrm{~cm}$ Private collection.

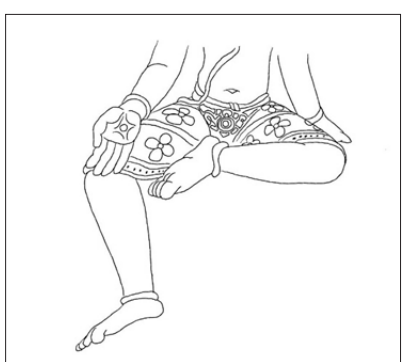

Figure 8a. Drawing of the textile pattern by Yiran Huang

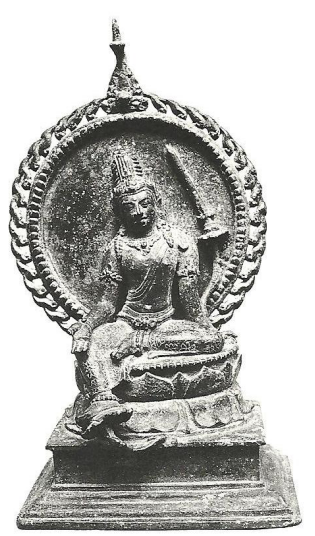

Figure 9. Sthiracakra, Central Javanese period. Pusat Penelitian Arkeologi Nasional, Jakarta. $29 \mathrm{~cm}$, bronze. Inv. no. unknown. Image from Fontein, Soekmono and Suleiman (1971, p. 150, no. 38).

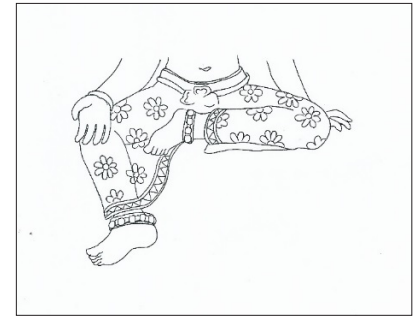

Figure 9a. Drawing of the textile pattern by Yiran Huang describes the textile pattern as 'floral' (1990:194). Bernet Kempers has proposed that this sculpture came to Java at the beginning of the 10th century (1959:52). I argue that as the figure exhibits very little of a Javanese aesthetic, we know from this period; however, the depiction of the eyes reflect Pāla features.

The face appears more closely to Java than to India and replicates the Indian physiognomy. Of particular interest is the carved textile pattern on his kain, finely executed with precision, which is possible in silver compared to the smaller bronze statues. The pattern could be interpreted as a vajra in the form of the fleur-de-lis as a stylised lotus flower, synonymous with Buddhism, depicted in horizontal bands, as seen in figure 7a. (Pullen, 2021:95).

On the other hand, one aspect that differs considerably is the strong brow line. I re-interpret this statue and argue it is partly due to the metal being used and is a feature that is also evident in some of the Indian statues. From the relatively large size, one can surmise that the statue was probably cast in Java, perhaps by an Indian artisan for a person of the highest status. Inside a loop that existed at the base of the statue, now-lost is a single silver sheet fragment of the Buddhist Creed written in Siddhamātrkā script (Fontein, 1990:189 \& 194). As a significant silver figure of this quality, unknown in India or indeed in China at this period, this icon remains an excellent example of Javanese metal casting.

The last statue in this group remains in a Private
Collection and is unpublished except in Patterned Splendour, Pullen 2021. This example of Mañjuśrī (Fig. 8) (2021:91) bears all the similar features as figure 5 , except in this instance, he is adorned with the tiger-claw necklace and carved with a textile pattern which displays is a simple four-petal flower set in horizontal bands (Fig. 8a). Close analysis of the facial features illustrates that an Indian artisan could have also made this statue in Java. However, the statue does not appear to reflect the 'sweetness' of the classic Javanese bronzes as the carving of the eyes and lips do not reflect a true Javanese style.

These next small seated Mañjuśrī differ entirely from the previous examples. Figure 9, believed to be an example of Sthiracakra as described by Bhattacharya (1924:122), with the sword depicted on the lotus on the left side cast against the backplate with the lotus stem held in the left hand and the right leg pendant in lalitāsana. His hair is piled but also appears in ringlets falling over both shoulders. The ornaments are simple; a broad seléndang draped across the body, kain falls to the ankles, patterned with an overall design of daisy flowers (Fig. 9a) I would argue that other Indian features apparent in depicting the flames around the halo, the lines in the sash and the overall physiognomy.

\section{East Java Mañjuśrī Arapacana Biography of the Object}

This sculpture deserves a little more attention than the 
previous icons discussed in this chapter as it is one of a kind in the pantheon of Central and East Javanese sculptures. Additionally, it has a fascinating biography.

Nicolaus Engelhard, the Governor-General of the North Coast of Java from 1801 to 1808 , commissioned in 1808 a scale chalk drawing of Mañjuśrī Arapacana. In 1823 the sculpture was collected by Engelhard. It was taken to Batavia and subsequently shipped to the Netherlands. In the same year, a drawing by J. Th Bik appeared as a full page in a publication by Brandes (1909:81). In 1828 the statue stood in Ziudlaren, in the garden of Engelhard's sister, too heavy to take inside. Upon her death around 1860, her heirs sold the statue to auctioneers ${ }^{11}$ in The Hague, the Groote Koninklijke Bazar (Le Bazar Royal) owned by Dirk Boer in The Hague to the new Ethnographical Collection in Berlin. In 1857 Friederich saw the drawings collected by Engelhard and began translating the two inscriptions on the front and reverse of the stone. The inscriptions are in Sanskrit and dated to 1265 . In 1860 , the auctioneers sold the statue then moved it to the new Ethnological Collection in Berlin. ${ }^{12}$ In March 1861, Friederich showed Dr C Leemans, the Director of the Berlin Museum for antiquities, who saw an image of the statue and the two inscriptions, which Leemans recognises as the statue placed in the garden of the grand bazaar (1864:494-7). The statue was subsequently acquired from Dutch sources and placed in the Berlin Ethnographical Museum (Stutterheim, 1932:47). ${ }^{13}$

The sculpture was moved in 1941 for security reasons to the Berlin "Flaktürme Zoo" and secured in the godown bunker for art objects. Shortly after the end of hostilities in $1945^{14}$, the statue was transferred, along with other art objects, to the former Soviet Union and then to Leningrad. Following the first convocation of the State Duma (Assembly) of the Russian Federation in 1995, when such art objects were considered Russia's property, the statue then assigned to the State Hermitage Museum in St Petersburg. A list of missing holdings since $1945^{15}$ from the former department of the Museum of Folklore (today's Museum fur Indische Kunst) in Berlin and published in Berlin in 2002. The book of 'lost' sculptures, Dokumentation der Verluste, Band 3, shows Mañjuśrī on page 93 no. 1065. The document records the statue was a gift from De Boer to The State Hermitage Museum, St Petersburg. Berlind 1864, the Mañjuśrī was first seen, and not again until a three-month exhibition in 2016 in St Petersburg. ${ }^{16}$

\section{Description}

The dating of this statue is not related to the temple of Candi
Jago but instead using stylistic features, which would put this statue closer to the attendants of Amoghapāsáa ${ }^{17}$ dated to $1280 \mathrm{CE}$ (P Lunsingh Scheurleer, 2008:296). Lunsingh Scheurleer suggests: "A Mañjuśrí statue is entitled to a separate shrine; the statue seems to be rather small for this large building. If at Caṇdị Jago, Mañjuśrī was placed in a separate shrine in the compound"(2008:ibid). Raffles thought that Mañjuśrī would have been placed in a cella or niche on an elevated terrace about twelve feet tall at the top of the sanctuary (1817:45 Vol 2). He describes that at a short distance from Jago was an image of a man, peculiar by the way his hair is tied. The description by Raffles, suggesting that the statue must have a separate shrine or platform, would seem appropriate and logical, as the statue sits against a backplate. This image of Arapacana does indeed have such a hairstyle.

The sculpture commissioned by a Sumatran prince, who later became King Ādityavarman (r. c. 1347-1379). On the front and the reverse of the backplate are inscriptions dated to $1343 \mathrm{CE}$. The inscriptions were added at a later date since their script shows different hands. Translated by Bosch (1921) into Dutch and later into English (Kozok and Reijn (2010:139-43). ${ }^{18}$ The statue should be dated to $1268 \mathrm{CE}$, the time of the śraddha $\bar{a}^{19}$ ceremony enacted for the Buddhist temple known as Candi Jago. Ādityavarman ordered the building of a temple to house Mañjuśrī and foster the Dharma (2010:ibid; Schnitger, 1937:9). It is unknown whether the statue was placed at Jago or in its pavilion, as suggested earlier (Kozok \& Reijn, 2010:143). Miksic indicates its findspot is unknown and has suggested that Ādityavarman "did espouse a form of Buddhist doctrine which included Mañjuśrī as an important figure" (2006:206-7).

\section{Iconography}

The notable resurgence of Mañjuśrī Arapacana at Caṇ̣ii Jago highlights the autonomy and innovation of Java at least one hundred years after such a Buddhist cult subsided in eastern India. There appears to have been a latent resurgence of art styles from Bengal in this statue of Arapacana (Bautze-Picron, 2016:166), overlaid with a local indigenous style. The Hermitage Arapacana's face deep in meditation depicts a certain realism of human features or divine perfection. This figure contrasts with earlier Pāla Arapacana bronzes in whose features are considerably more stylised. His chest is broad, and his belly appears sucked in, which might suggest he is in "Yoga Prānāyāma". This feature is apparent in many Central Javanese bronzes figures, but not in Indian statues. Thus, I would argue, this aspect may reflect an earlier post-Gupta/early Pāla period. 


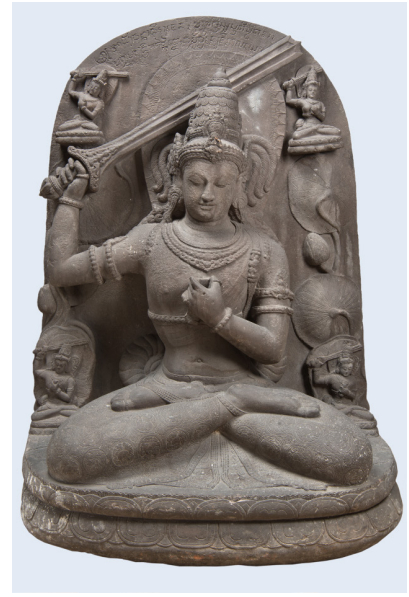

Figure 10. Mañjuśrī

Arapacana. Caṇḍi Jago, East Java, dedicated in 1265 and inscribed in $1343 \mathrm{CE}$, State Hermitage Museum, St Petersburg (in storage). Acquired in 1945 from Museum für Völkerkunde, Berlin. 1m, andesite stone. Inv. no. BD-610.

The smooth surface of the Arapacana statue carved with discreet ornaments includes the udarabhanda or stomacher formed with raised circular-shaped plaques. The statue wears a headdress or kiritamukuta; the seléndang is depicted as broadband across the upper body, over which the upavita falls carved to resemble a five-stranded string of pearls falling over the feet, and finishes with an ornate clasp at the left shoulder. The kain held with a girdle whose ends lie under the lower legs, finishing with metal tassels. This garment overlaid with a plain double sash, carved with a simple pattern of lines and circles. The ends hang to the side of the body tied in an overly large bow shown against the backplate, in typical Singhasāri fashion (Pullen, 2021:12-13, 207-08), along with the lotus flower growing from the roots beside the rear of the body. ${ }^{20}$

The sinjang carved with a complex pattern of concentric circles made up of four different designs, alternating and repeated across the cloth (Fig. 10a). The carving of the patterns is very clear and precise and appears to reflect several different influences, often depicted on Sassanian textiles. This idea may suggest that textile patterns were transmitted to Java from following long-distance trade, for instance, from the royal courts in Yuan China to the Javanese court, where the competing monarchs, Kublai Khan and Kṛtanāgara, practised
Esoteric Buddhism. It seems reasonable to suggest that such a textile could have reached Java as part of Chinese gift exchange or through Arab traders from Persia. ${ }^{21}$ Other examples of textile patterns with animal roundels found on 11th and 12th-century ceiling mural paintings are at Bagan. ${ }^{22}$ Acri describes one of the 11 th-century temples at Bagan, which displays Mahāyānic/Tantric features, which he proposes may result from the cultural-diplomatic links and marital relationships between the rulers of Pagan and those in Bengal (2016:20). Mahler discusses (1958:40) that the influence of Pāla sculpture had a direct bearing on the Burmese temple paintings, where there is evidence of mythical animals in roundels in the garments of a king. The detailed textile pattern displayed by Javanese statues would seem to echo an earlier period in Asian history and textiles within the Southeast Asian and Chinese region.

\section{CONCLUSION}

This paper has briefly looked at the career of the Bodhisattva Mañjuśrī from Wutai Shan in China to Pāla India and Central and East Java. Mañjuśrī, known as Wénshū in China, resided in Wutai Shan, one of China's premier Buddhist pilgrim sites. Literature shows him as the first bodhisattva to appear in the Chinese Tang court, where he was called upon to help devotees. Subsequent rulers glorified Mañjuśrī as the protector of both king and kingdom.

In summary, art historians used 'style and iconography' as a sculpture identifier, where the date and place of origin are often irrelevant, incorrect, or unknown. Therefore, as an example, we use the style of a few Javanese statues that display crescent moons or wings appearing behind the head to identify a Kumāra from Central Java. Consequently, despite Miksic's theories, one can argue this innovation is probably of Central Javanese origin and appears an unknown feature in India, only prevalent in Central Java statues; hence the iconography alone is the sole means of identification.

The framework of this paper has grouped these commonly seen Kumāra sculptures and placed them together, and shown that the statues of Mañjuśrī created in Central Java are unique and do not appear in this particular form anywhere else in the Buddhist world. Similarly, the 13th-century Arapacana is the only known icon testifying to a later Buddhist resurgence in East Java under the Singhasāri dynasty. Accordingly, by re-interpreting and examining the textile patterns on the sculptures of Mañjuśrī, we can cast a light on the Buddhist ideas and fabric types in circulation at any one given period. Thus, it highlights acculturation and the eventual adoption of 
foreign ideas by the local craftsman.

This article concludes with a detailed discussion on the Arapacana statue from East Java, summarising its path from its origin at Caṇi Jago to its final resting place at the State Hermitage Musem. This statue's scale, power, and mandalic force affirm the blossoming of this celestial boddhisattva in Java long after being eclipsed in Pāla, India.

\section{ENDNOTES}

1) According to evidence in the Svāyambhupurāna, Mañjuśrī is said to have left Mount Pancaśirșa (the hill of five peaks) in China and cleaved apart mountains with his sword to release the waters of Lake Kālīhrada into India to drain the Kathmandu valley, which owe its creation to Mañjuśrī, as advocated by Gail.

2) Bhattacharya notes that the group originates from, and reflects, the bija mandala of five sounds that make up the name of Arapacana, viz. A-Ra-Pa-Ca-Na (1958:120-1), where he appears with four companions (Sūryaprabha, Candraprabha, Keśinī, and Upakeśinī).

3) The statue was bought at auction in Europe in 2018 from a Chinese collector from Singapore with a good provenance, but the rather bulbous nose and incised eyes and simple ornaments lead me to believe this is an early 9th bronze from Bangladesh or Odisha found in Java. This Mañjuśrī is also adorned with the tiger claw necklace and a simply patterned long cloth similar in the form to a Javanese kain. This bronze highlights the early history of bronze icons that were traded from Indian to Java and vice versa.

4) Charms or procedures for worship.

5) https://mandalas.life/2019/depicting-5-forms-ofmanjushri-thangka/

6) The southeast coast of Sumatra, the north coast of Java and the southern coast of Thailand were ready markets for the trade of silks, cotton, and porcelains. While the merchants were of Persian and Indian origin, the ships and sailors were Southeast Asian (Wolters 1967:150).

7) $S M 44,45,55,56$.

8) During my field work in 2019 I was unable to find this statue.

9) https://www.agefotostock.com/age/en/details-photo/ plaosan-manjusri-not-in-situ-candi-borobudurindonesia/ZQ5-2779004. This example displays similar iconography as in figure $1 \& 2$, but in this instance, the triangular wings are visible on the backplate along with the book placed the lotus, the decoration around the ogival backplate is of the same style as figure $1 \& 2$.

10)Figure 3 was last published in 2019 as part of the British Museum Raffles exhibition (but with no description).
11) Great Royal Bazaar of D. Boer and Sons.

12) The Berlin Museum was founded in 1873 , but the doors did not open until 1886. In 1864 the statue was exhibited and published by R.H. Th. Friederich in Zeitschrift der Deutschen Morgenländischen Gesellschaft.

13)Along with the statue of Harihara Ardhnari see Author (2021:203-06). There appears some conflicting information concerning the dating of what actually happened during this period.

14)Fairey Battle - Wikipedia. https://en.wikipedia.org/wiki/ Fairey_Battle.

15) The objects were shipped to Petersburg as a compensation for German activities and destructions in Russia. They are considered Russian possessions after the Duma resolution (personal communication Dr Caren Dreyer).

16) Sacral Gifting to Deity: Southeast-Asia Sculpture of the 8th-20th centuries from the State Hermitage Collection, the exhibition ran from 13-02-2016 to 08-05-2016.

17)Jago still has in situ a damaged statue of Amoghapāśa Lokeśvara. His attendants Hayagrīva, Sudhanakumāra, Śyāmatārā and Bụkuṭī are in the Museum Nasional in Jakarta.

18) ' $\mathrm{He}$, Addityavarman in the realm ruled by her majesty the supreme queen, from her lineage, having true intentions, endowed with excellent qualities, the highest ranking servant of the state, on Javanese soil, in the city of the Buddha temple, built an amazingly beautiful temple, to guide his parents and kin from the sublunary existence to the joys of nirvana' (Kozok and Reijn 2010:139). Kozok and Reijn have suggested that as the inscription was written in Sanskrit it is perhaps another indication of the patronage of A dityavarman. However, this aspect is rather ambiguous from the translation. Ādityavarman built Caṇ̣i Jago to guide his parents and kin from this existence to Nirvana, however one of his kin was the queen in whose service he was employed (2010:141).

19) The śraddha ceremony is carried out 12 years after the death, for which reason Caṇịi Jago was built by King Kṛtanagara in memory of his father.

20)Details on Mañjuśrī Arapacana taken from Author 2017.

21) The only evidence for attributing this textile pattern to Persia is this sculpture. Amy Heller describes the movement of designs "from Persia to China, medallions of single or confronting animals with a pearl roundel were among the most popular designs of the period. The creatures were frequently imaginary or hybrid birds or animals" (Heller 1998:183).

22) From empirical evidence visiting Bagan in 2015 , to the Nampaya and Abeyadana temples. 


\section{BIBLIOGRAPHY}

Acri, A. (2016). Introduction: Esoteric Buddhist Networks along the Maritime Silk Routes, 7th -13th Century AD. In A. Acri (Ed.), Esoteric Buddhism in Medieval Maritime Asia (pp. 1-29). Singapore: ISEAS.

Bautze-Picron, C. (2007). Sculpture. a. Ancient Period. In S. Lala Rukh (Ed.), Fine Arts and Crafts (pp. 91-109):

Dhaka: Asiatic Society of Bangladesh.

Bautze-Picron, C. (2016). Shiva and Umâ, Manjushrî, Narasimha seated astride Garuda. In $A$ World of Sculptures, ed. KARIM \& ISABELLE GRUSENMEYER-BILQUIN, DAMIEN WOLINER (pp. 4-7, 14-22). Bruxelles: Grusenmeyer/Woliner.

Bautze-Picron, C. (1989). Some Aspects of Mañjushrî's Iconography in Bihar from the 7th century onwards. Tribus, Jahrbuch des Linden-Museums, 38, 71-90.

Bernet Kempers, A. J. (1959). Ancient Indonesian Art. Amsterdam: C. P. J. van der Peet, .

Bhattacharyya, B. (1924). The Indian Buddhist Iconography: Mainly based on the Sadhanamala and other Cognate Tantric Texts of Rituals. New Delhi: Aryan Books International.

Bhattacharyya, B. (1958). Indian Buddhist Iconography (2nd ed.). Calcutta: Mukhopadhyay, K.L.

Bosch, F. D. K. (1921). De Inscriptie op het Manjusri beeld van 1265 Saka. BKI, 77, 194-201.

Bosch, F. D. K. (1961). Selected Studies in Indonesian Archaeology. The Hague: Martinus Nijhoff

Brandes, J. L. A. (1904). Beschrijving van de ruïne bij de desa Toempang, genaamd Tjandi Djago : in de residentie Pasoeroean. 's-Gravenhage : Batavia: M. Nijhoff

Brandes, J. L. A. (1909). Beschrijving van Tjandi Singasari [microform] : en de wolkentooneelen van Panataran Batavia: M. Nijhoff; Albrecht \& co., .

Degroot, V. (Ed.) (2013). Magical Prambanan. Yogjakarta: PT (Persero) Taman Wisata Candi.

Deshpande, O. (2016). Works of Art From Southeast Asia. St Petersburg: The State Hermitage Publishers.

Dumarçay, J. (1981). Candi Sewu and Buddhist Architecture of Central Java (J. Miksic, Trans.). Jakarta: Ecole francaise d'Extreme-Orient.

Fontein, J. (1990). Sculpture of Indonesia. New York: Harry N. Abrams, Inc.

Friedrich, R. (1864). Über 2 Inschriften auf einem Bilde des Mandjuçrî, jetzt im Neuen Museum zu Berlin. Zeitschrift der Deutschen Morgenländischen Gesellschaft, 18, 494-508.

Gail, A. (1995). Manjusri and his Sword. Paper presented at the Function and Meaning in Buddhist Art, Leiden University.

Huntington, S., L, \& Huntington, J., C. (1990). Leaves From the Bodhi Tree:The Art of Pala India (8th-12th
Centuries) and Its International Legacy. Seattle and London: Dayton Art Institute.

Jordaan, R. E. (1993). Imagine Buddha in Prambanan: Reconsidering the Buddhist Background of the Loro Jonggrang Temple Complex. Rijksuniversiteit te Leiden: Vakgroep Talen en Culturen van ZuidoostAzie en Oceanie.

Kieschnick, J. (2015). Building a Sacred Mountain: The Buddhist Architecture of China's Mount Wutai. [Building a Sacred Mountain: The Buddhist Architecture of China's Mount Wutai, Wei-Cheng Lin]. The Journal of Asian Studies, 74(1), 199-200.

Kozok, U., \& Reijn, v. (2010). Adityawarman: Three Inscriptions of the Sumatran 'King of all Kings'. Indonesia and the Malay World, 38(110), 135-158.

Long, M. E. (2015 Nov). An Eighth-century Commentary on the Namasangiti and the Cluster of Temples on the Prambanan Plain in Central Java. . NSC Working Paper, No 20, 1-24.

Lunsingh Scheurleer, P. (1988). A Particular Central Javanese Group of Bronzes. Paper presented at the Studies in South and Southeast Asian Archaeology, Leiden.

Lunsingh Scheurleer, P. (2008). The Well-Known Javanese Statue in the Tropenmuseum, Amsterdam, and its place in Javanese Sculpture. Artibus Asiae, 68(2), 287-332. doi:10.2307/40599602

Lunsingh Scheurleer, P., \& Klokke, M. J. (1988). Divine Bronze: Ancient Indonesian bronzes from A.D. 600 to 1600. Leiden: Brill.

Mahler, J. G. (1958). The Art of Medieval Burma in Pagan. Archives of the Chinese Art Society of America, 12, 30-47.

Mallmann, M.-T. d. (1964). Étude iconographique sur Mañjuśrī. Paris: École française d'Extrême-Orient.

Maxwell, T. S. (1997). The Gods of Asia: Image Text and Meaning. Delhi: Oxford University Press.

Miksic, J. (2006). Manjusri as a Political Symbol in Ancient Java. In B. Dagens \& H. Chambert-Loir (Eds.), Anamorphoses : Hommage à Jacques Dumarçay (pp. 185-226). Paris: Les Antes Savantes.

Mitra, D. (1978). Bronzes from Achutrajpur, Orissa. Delhi: Agan Kala Prakashan.

Pullen, L. S. (2017). Representation of Textiles on Classical Javanese Sculpture. PhD Thesis, SOAS, London (4436, plus Vol 2 Appendices)

Pullen, L. S. (2021). Patterned Splendour: Textiles Presented on Javanese Metal and Stone Sculptures Eight to the Fifteenth Century. Singapore: ISEAS Publishing.

Raffles, S. S. (1817). The History of Java (Vol. II). London: Black, Parbury and Allen.

Reichle, N. (2007). Violence and Serenity, late Buddhist Sculpture from Indonesia. Hawaii: University of Hawaii Press. 
Robson, S., \& Prapanca, M. (1995). Desawarnana (Nagarakrtagama) (S. Robson, Trans.). Leiden: KITLV.

Schnitger, F. M. (1937). The Archaeology of Hindoo Sumatra. Leiden: E. J. Brill.

Sen, T. (2009). Changes and Exchanges. India International Centre Quarterly, 36(3/4), 34-47.

Snellgrove, D. L. (1987). Indo-Tibetan Buddhism: Indian Buddhists and their Tibetan successors. London: Serindia.

Soekmono, R. (1995). The Javanese Candi, Function and Meaning. Leiden: E.J. Brill.
Southworth, W., A. (2017). Twelve Stone Sculptures from Java. The Rijksmuseum Bulletin, 65(3), 245-274.

Stutterheim, W. F. (1932). Eine Statue des Javanischen Königs Krtanagara in Berlin? Berliner Museen, 53(3), 47-50.

Untracht, O. (1997). Traditional Jewellery of India. London: Thames and Hudson.

Wahyono, M. (1999). The Gold of the Archipelago. In D. Hall (Ed.), Indonesian Gold, Treasures from the National Museum, Jakarta. South Brisbane: Queensland Art gallery. 